\begin{abstract}
"Mircea cel Batran" Naval Academy Scientific Bulletin, Volume XX - 2017 - Issue 2
The journal is indexed in: PROQUEST / DOAJ / Crossref / EBSCOhost/ INDEX COPERNICUS/ OAJI / DRJI I

JOURNAL INDEX / I2OR / SCIENCE LIBRARY INDEX / Google Scholar / Academic Keys / ROAD Open Access I Academic Resources / Scientific Indexing Services / SCIPIOI JIFACTOR
\end{abstract}

\title{
FRACTAL DESIGN: A NEW PATH TO IMPROVE EMS ORGANIZATIONAL INTEGRATION ASSESSMENT PROCESS
}

\author{
lonut Viorel HERGHILIGIU \\ PhD Lecturer, Department of Engineering and Management, "Gheorghe Asachi" Technical University of Iasi, \\ 28 Prof. Dr. Doc. Dimitrie Mangeron Avenue, 700050, Iași, Romania; E-Mail: iherghelegiu@tuiasi.ro
}

\begin{abstract}
Sustainability has become a critical issue for today world and for the future of tomorrow. The issue of organizations sustainable development involves a new orientation which implies implementation and integration of effective management tools. Such a management tool considered as being a driving force to sustainable development and value creation is Environmental management system (EMS) design according with ISO 14001 or with EMAS. The current literature on the ISO 14001 EMS has largely neglected this phenomenon of integration (internalization). It is also necessary to mention that scientific literature shows only a few interdisciplinary studies on environmental management science that integrates the Fractal philosophy approach, and even less in the field of EMS. This paper presents a theoretical framework based on Fractal philosophy principles in order to assess the EMS organizational integration process.
\end{abstract}

Keywords: Fractal assessment methodology, EMS integration, ISO 14001, organizational sustainability.

\section{INTRODUCTION}

Sustainability has become a critical issue for today world and for the future of tomorrow. The sustainability issue can be considered as a consensual associated to business decisionmaking process of the organizations stakeholders/ shareholders [1]. Likewise it should be mention that this process must actively integrate three key elements: ecological resilience (i), people (ii), and profit (iii).

Corporate sustainable development implies application and integration various effective management tools. Such a management tool considered to be a driving force to sustainable development and value creation is Environmental management system (EMS) design according with ISO 14001 [2] or with EMAS [3]. These international standards, such ISO 14001 or EMAS provides to organizations a guidelines/ structure/ architecture which contributes to achieve environmental and economic goals. Likewise Through development and certification of EMS, organizations intend to respond to the concerns regarding sustainable development presented at the United Nations Conference on Environment and Development in 1992 (Rio de Janeiro). Therefore ISO 14001 EMS is the most common worldwide organizational environmental management tool [4]. Globally more than 319,324 organizations have implemented ISO 14001 guidelines in their businesses (until the year 2016) [5]. Likewise it should be mentioned the fact that environmental legislative context and the current complex business environment determines the orientation level or organizations to EMS implementation [3].

The main objective of this work is to present a theoretical framework based on Fractal philosophy principles in order improve the assessment process of EMS organizational integration.

This paper is organized as follows: Sect. 2 presents (a) organizational EMS integration context and (b) "relation" between Fractal design and EMS; Sect. 3 presents (a) general researched methodology used in order to develop the EMS integration assessment model (b) the proposed EMS integration assessment model based on Fractal philosophy principles. In the Sect. 4 it's presented the conclusions.

\section{ORGANIZATIONAL EMS INTEGRATION CONTEXT}

The literature emphasizes the fact that the ISO 14000 series and consequently EMS implementation lead to major benefits $[8,9]$ for the organizational management: "The ISO 14000 series has the potential to create dramatic improvements in organizational management that extend far beyond the management of organizational environmental impacts. ...." [10]. That's why organizations should implement and integrate EMS's.

However institutional theories (IT) and resourcebased views (RBV) presents the fact that even EMS's externally are similar (considering design schemes as ISO 14001 or EMAS), may be very differently implemented and integrated. Due to this non homogeneity implementation it can be observed a significant variation of this management systems performance [6]. The literature on ISO 14001 organizational certification/ EMS, "has largely neglected this phenomenon" [6, 7]; therefore it could be explain the "instability of findings from the empirical literature" [6] regarding EMS. Likewise Yin and Schmeidler (2009) argue that "in order to design measures to ensure integration, studies need to be done...." [6]. 
"Mircea cel Batran" Naval Academy Scientific Bulletin, Volume XX - 2017 - Issue 2

The journal is indexed in: PROQUEST / DOAJ / Crossref / EBSCOhost/ INDEX COPERNICUS/ OAJI / DRJI I JOURNAL INDEX / I2OR / SCIENCE LIBRARY INDEX / Google Scholar / Academic Keys / ROAD Open Access I

\section{FRACTAL DESIGN AND EMS} Academic Resources / Scientific Indexing Services / SCIPIOI JIFACTOR

One of the scientists' major preoccupations consists in understanding systems (regardless of the system's type and nature). This understanding approach relies on the following idea: if there are enough data, information and knowledge (if it is the case) about a system, then the system's behavior can be forecasted. Having in view that any kind of systems could be approached in order to be analyzed, the introduction of the Fractal theory represents one of the most important events in the contemporary science [12]. A fractal is characterized in essence as being "the set of reduced dimensions that generate rules when the information is randomly general" [35, 12].

The Fractal philosophy started to be used on organizational theory and systems' behavior more than two decades ago. In the literature exist a series of scientific articles and books that presents this interdisciplinary approach with the main purpose to improve organizational performance [11].

Table 1 presents some representative authors that develop an interdisciplinary approach based on Fractal principle regarding (a) organizational architecture, (b) organizational informational system, (c) quality management and control, (d) knowledge management and the decisional process, (e) organizational management systems architecture, (f) logistic management, (g) production systems development, and so on [12]. Likewise it is also necessary to mention that scientific literature shows only a few interdisciplinary studies on environmental management science that integrates the Fractal philosophy approach, and even less in the field of EMS.

Table 1. Synthesis regarding interdisciplinary approaches based on Fractal principle [12]

\begin{tabular}{lll}
\hline ANALYSED ISSUE & REFERENCE & REMARKED ASPECTS \\
\hline INFORMATIONAL & {$[13,14,15,16$,} & * fractal theory allows application of various methods regarding \\
ORGANISATIONAL & $17]$ & $\begin{array}{l}\text { system development on different organizational administrative } \\
\text { levels; it leads to informational process development acceleration }\end{array}$ \\
SYSTEM & & $\begin{array}{l}\text { and system's management (informational system) change; * } \\
\text { information architecture dynamic and Fractal informational } \\
\text { system; }\end{array}$
\end{tabular}

ORGANISATIONS' $\quad[11,13]$
ARCHITECTURE

a. adaptation regarding organizations' properties with Fractal architecture;

b. opportunities and limitations identification regarding the use of organizations' characteristics with fractal architecture in the companies' models analysis;

[18] *Fractal architecture;

\begin{tabular}{lll} 
& {$[19]$} & $*$ organization's change management by using Fractal philosophy; \\
\hline QUALITY & {$[20,21]$} & * evaluation methodology development and quality analysis \\
MANAGEMENT AND & & relying on Fractal principles; \\
CONTROL & * continual improvement process as Fractal structure for \\
& managerial processes and for continual improvement required by \\
& ISO 9001 standard;
\end{tabular}

\begin{tabular}{|c|c|c|}
\hline $\begin{array}{l}\text { KNOWLEDGE } \\
\text { MANAGEMENT AND } \\
\text { DECISIONAL } \\
\text { PROCESS }\end{array}$ & $\begin{array}{l}{[22,23,24,12,} \\
25]\end{array}$ & $\begin{array}{l}\text { * application of Fractal philosophy on knowledge management } \\
\text { regarding human resource (investigation methodology, and so } \\
\text { on); } \\
\text { * application of Fractal philosophy on environmental decisional } \\
\text { process; }\end{array}$ \\
\hline $\begin{array}{l}\text { ENVIRONMENTAL } \\
\text { MANAGEMENT } \\
\text { SYSTEM (EMS) } \\
\text { ARCHITECTURE }\end{array}$ & {$[12,26]$} & $\begin{array}{l}\text { * transformation regarding EMS implementation and integration } \\
\text { process based on Fractal philosophy; }\end{array}$ \\
\hline $\begin{array}{l}\text { PRODUCTION } \\
\text { SYSTEMS } \\
\text { DEVELOPMENT }\end{array}$ & {$[20,27,28]$} & $\begin{array}{l}\text { * development of methods/ models in order to increase the } \\
\text { production systems efficiency relying on Fractal theory; }\end{array}$ \\
\hline $\begin{array}{l}\text { PRODUCTION } \\
\text { SYSTEMS } \\
\text { ORGANISATION } \\
\text { ACCORDING TO } \\
\text { FRACTAL } \\
\text { PRINCIPLES }\end{array}$ & $\begin{array}{l}{[29,30,31,32,} \\
33]\end{array}$ & $\begin{array}{l}\text { * defining the Fractal architecture of production systems and of } \\
\text { Fractal entities; } \\
\text { * comparison between the hierarchical architecture and the } \\
\text { Fractal one; } \\
\text { * description of the Fractal agents associated to each Fractal } \\
\text { module; } \\
\text { * description regarding the orientation mechanism of the Fractal }\end{array}$ \\
\hline
\end{tabular}


"Mircea cel Batran" Naval Academy Scientific Bulletin, Volume XX - 2017 - Issue 2

The journal is indexed in: PROQUEST / DOAJ / Crossref / EBSCOhost/ INDEX COPERNICUS/ OAJI / DRJI I JOURNAL INDEX / I2OR / SCIENCE LIBRARY INDEX / Google Scholar / Academic Keys / ROAD Open Access I Academic Resources / Scientific Indexing Services / SCIPIOI JIFACTOR

\begin{tabular}{|c|c|c|}
\hline & & entities' objectives; \\
\hline $\begin{array}{l}\text { LOGISTIC } \\
\text { MANAGEMENT }\end{array}$ & [34] & $\begin{array}{l}\text { * representative Fractal unit design for the organizations provision } \\
\text { chain. }\end{array}$ \\
\hline
\end{tabular}

\section{GENERAL RESEARCHED METHODOLOGY}

The general research methodology used in order to develop/ design a theoretical framework based on Fractal philosophy principles in order to assess the EMS organizational integration process could be observed in Figure 1.

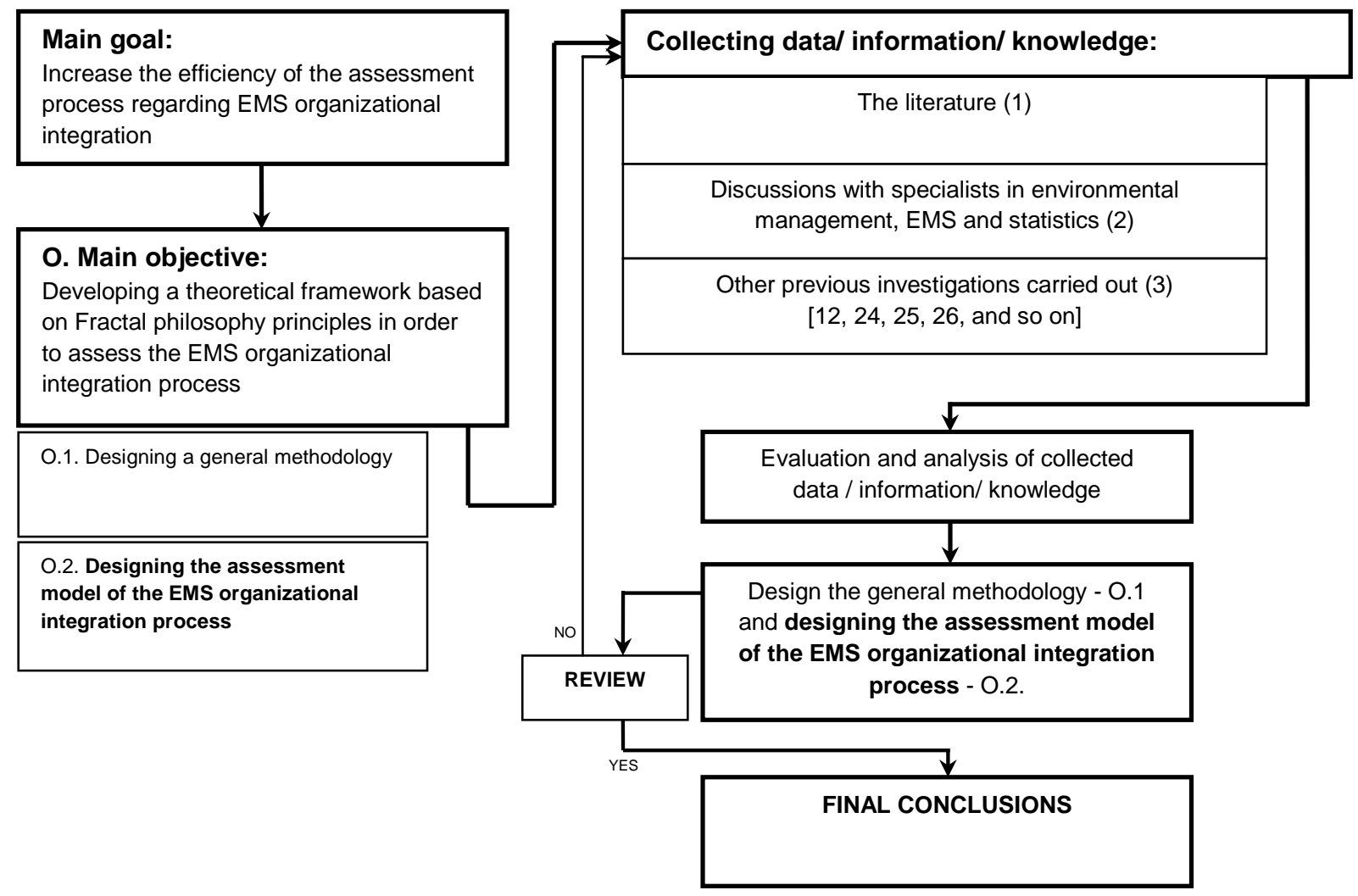

Figure 1. General research methodology

\section{EMS INTEGRATION ASSESSMENT MODEL BASED ON FRACTAL PHILOSOPHY PRINCIPLES}

Environmental management system (EMS) is defined by ISO 14001 as being "a component of the general management system that includes the organizational structure, planning activities, responsibilities, practices, procedures, processes and resources in order to elaborate, implement, achieve, analyze and maintain the environmental policy" [36, 37, 38]. Thus organizational integration of such a management system implies that companies absorb/ institutionalize all the environmental practices associated to EMS. Therefore EMS organizational real application involves routinization of environmental (a) planning and organizing, (b) operational, and (c) communicational practices.
Consequently a "central element" of the assessment model (Figure 2) will be the indicators associated to EMS organizational integration (established based on principals and criteria's associated to EMS organizational implementation), namely environmental (1) organization policies, (2) resources allocation, (3) operational control and documentation, (4) support and information systems, (5) training and development, (6) organization and structure of responsibilities, (7) appreciation and reward systems, (8) measuring and monitoring systems, (9) communication and reporting. Likewise based on the Fractal theory principles and auditing principles [39] each indicator associated to EMS integration, must be evaluated/ analyzed considering next phase: (A) monitoring, (B) information and communication, (C) control activities and environment, and (D) risk assessment. Still extremely important is the fact 
"Mircea cel Batran" Naval Academy Scientific Bulletin, Volume XX - 2017 - Issue 2

The journal is indexed in: PROQUEST / DOAJ / Crossref / EBSCOhost/ INDEX COPERNICUS/ OAJI / DRJI / JOURNAL INDEX I I2OR / SCIENCE LIBRARY INDEX / Google Scholar / Academic Keys I ROAD Open Access I Academic Resources / Scientific Indexing Services I SCIPIOI JIFACTOR

that this evaluation must be operated at the level of all organizational units, systems, processes, activities. Finally could be obtained the level regarding EMS organizational integration performance which must play a fundamental role in the organizational strategy associated to corporate sustainable development.

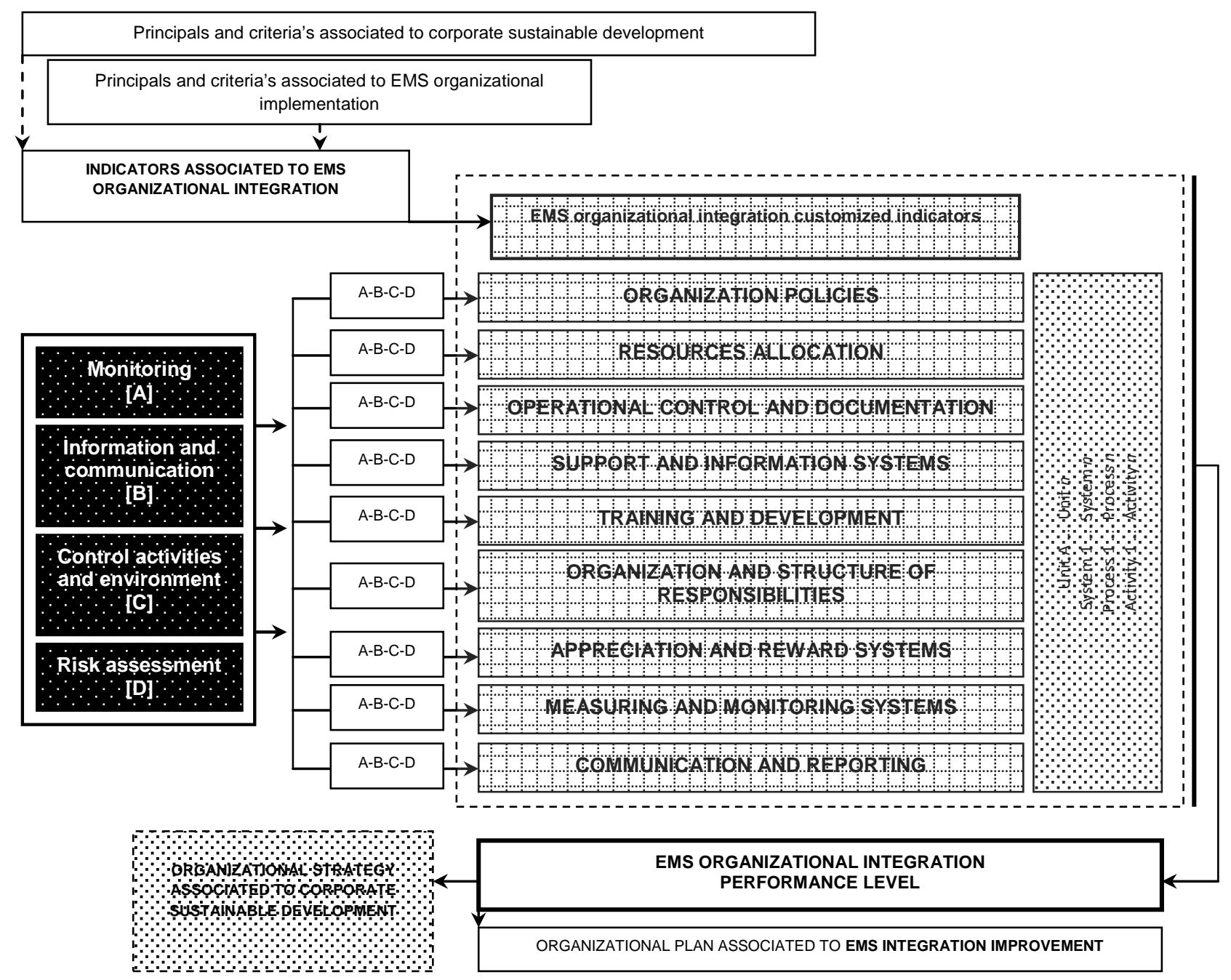

Figure 2. EMS integration assessment model based on Fractal philosophy principles

\section{CONCLUSIONS}

Sustainability has become a critical issue for today world and for the future of tomorrow. Starting from this previous statement, organizations must act responsible and to do so it must integrate various management systems (as EMS, QMS, CSR management system, and so on). This organizational integration is an extremely complicated process which requires different innovative management tools that can help managers in this endeavor. Therefore the main goal of this paper is to increase the assessment process efficiency regarding EMS organizational integration through development of an innovative assessment model based on Fractal philosophy principles. This proposed model could generate various effects as: (1) increase the organizational managers knowledge level regarding (i) the EMS organizational integration process, (ii) bidirectional relation between EMS integration and business performance, (2) increase the management awareness level regarding the EMS integration (institutionalization/ absorption) process, (3) increase the efficiency, effectiveness and economy level of the EMS integration process, (4) setting realistic management plans associated to EMS integration process, (5) even development of expert systems associated to EMS integration process. Likewise it should be mention the fact that this proposed managerial instrument could increase (as a medium and long-term organizational effect) the overall dynamic quality of EMS integration (institutionalization/ absorption) in order to enhance business performance.

Concluding it should be noted also that this paper has important theoretical and practical implications due to the fact that (1) the current literature on the ISO 14001 EMS "has largely neglected this phenomenon" [6, 7] of integration, (2) the literature shows only a few interdisciplinary studies on environmental management 


\begin{abstract}
"Mircea cel Batran" Naval Academy Scientific Bulletin, Volume XX - 2017 - Issue 2
The journal is indexed in: PROQUEST / DOAJ / Crossref / EBSCOhost/ INDEX COPERNICUS/ OAJI / DRJI I

JOURNAL INDEX I I2OR / SCIENCE LIBRARY INDEX / Google Scholar / Academic Keys / ROAD Open Access I Academic Resources / Scientific Indexing Services I SCIPIOI JIFACTOR
\end{abstract}

science that integrates the Fractal philosophy approach, and (3) in the literature exist a major gap associated to managerial instruments (models) that could assets the integrations organizational process of various management systems.

\title{
BIBLIOGRAPHY
}

[1] Mukherjee A., Vijayan G., Kamarulzaman N.H., Vaiappuri S.K.N., (2016), Sustainability: A Comprehensive Literature, in Handbook of Research on Global Supply Chain Management, Christiansen B. (ed), IGI Global, ISBN 9781466696402 (ebook).

[2] Sebhatu S.P., Enquist B., (2007), ISO 14001 as a driving force for sustainable development and value creation, The TQM Magazine, 19 (5), 468-482.

[3] Wijesooriya C., Xu D., Green P., (2011), The Role of EMS in Environmental and Organizational Performance, National EMS Conference, Geelong, Vic., Australia, 1-5.

[4] Ong T.S., The B.H., Ng S.H., Soh W.N, (2016), Environmental Management System and Financial Performance, Institutions and Economies, 8 (2), 26-52.

[5] International Organization for Standardization - ISO, (2016), ISO Survey: Survey data - ISO 14001; available at: http://www.iso.org/iso/iso-survey.

[6] Yin H., Schmeidler P.J., (2009), Why Do Standardized ISO 14001 Environmental Management Systems Lead to Heterogeneous Environmental Outcomes?, Business Strategy and the Environment, 18, 469-486, Published online in Wiley InterScience.

[7] Tari J.J., Molina-Azorin J.F., Heras I., (2012), Benefits of the ISO 9001 and ISO 14001 standards: A literature review, J of Industrial Engineering and Management, 5 (2): 297-322.

[8] Heras-Saizarbitoria I., Landin G.A., Molina-Azorin J.F., (2011), Do drivers matter for the benefits of ISO 14001?, International Journal of Operations \& Production Management, 31 (2), 192-216.

[9] Tari J.J., Molina-Azorin J.F., Heras I., (2012), Benefits of the ISO 9001 and ISO 14001 standards: A literature review, Journal of Industrial Engineering and Management, 5 (2), 297-322.

[10] Epstein M. J., Roy M.J., (1997), Using ISO 14000 for improved organizational learning and environmental management, Environmental Quality Management, 21-30.

[11] Sandkuhl K., Kirikova M., (2011), Analysing Enterprise Models from a Fractal Organisation Perspective Potentials and Limitations, The Practice of Enterprise Modeling, Proceedings of 4th IFIP WG 8.1 Working Conference, PoEM 2011 Oslo, Norway, November 2-3, 193-207.

[12] Herghiligiu I.V., 2013, Researches regarding environmental management system as a complex process at the organizational level, Doctoral Thesis, University of Angers, ISTIA, France.

[13] Kirikova M., Piciocchi P., Bassano C., Makṇa J., Stecjuka J., (2011), IS Based Best Process Practices Propagation in Fractal Enterprises: a Viable Systems Perspective, Proceedings of the 10th International Conference on Business Informatics Research (BIR 2011), Niedrite L., Strazdina R., Wangler B. (Eds.), Latvia, Riga, 54-62.

[14] Kirikova M., (2009a), Towards Flexible Information Architecture for Fractal Information Systems, Proceedings of International Conference on Information, Process, and Knowledge Management, 135-140

[15] Kirikova M., (2009b), Towards multifractal approach in IS development, Information Systems development: Challenges in Practice, Theory and Education, Vol. 1. Barry Ch., Conboy K., Lang M., Wojtkowski G., si Wojtkowski W. (Eds.), Springer, 295-306.

[16] Stecjuka J., Makna J., Kirikova M., (2008), Best practices oriented business process operation and design, In Proceedings of the 9th Workshop on Business Process Modeling, Development and Support Business Process Life-Cycle: Design, Deployment, Operation \& Evaluation Proceedings of the BPMDS'08 Workshop held in conjunction with the CAiSE'08 conference Montpellier, France, June 16-17, 2008, CEUR, 171-184.

[17] Grabis J., Kirikova M., Vanags J., (2009), Information architecture of fractal information systems, Proceedings of the 11th International Conference on Enterprise Information Systems, ISAS, Milan, Italy, 150155.

[18] Malan R., Bredemeyer D., (2010), The art of change: Fractal and emergant, Enterprise Architecture, 13 (5), 1-25.

[19] Strazdina R., Kirikova M., (2010), Change management for fractal systems, 19th International Conference on Information Systems Development, Prague, Czech Republic, 1-12.

[20] Qin Y., Zhao L., Yao Y., Xu D., (2007), A study of inter-enterprise quality control function selforganization reconfiguration based fractal networks, Proceedings of the 2007 IEEE International Conference on Robotics and Biomimetics, IEEE, 1733-1737.

[21] Prisecaru B.., Nicolescu D., Persideanu V., Moise A., (2012), The process approach as a fractal structure for continuous improvement of the organizations, U.P.B. Sci. Bull., Series D, 74 (3), 253-266.

[22] Xu J., Chen Ch., (2010), Similarity in tacit knowledge of supply chain and interfaces, IEEE 978-1-4244$7161-4 / 10,5$. 
"Mircea cel Batran" Naval Academy Scientific Bulletin, Volume XX - 2017 - Issue 2

The journal is indexed in: PROQUEST / DOAJ / Crossref / EBSCOhost/ INDEX COPERNICUS/ OAJI / DRJI I

JOURNAL INDEX / I2OR / SCIENCE LIBRARY INDEX / Google Scholar / Academic Keys / ROAD Open Access I Academic Resources I Scientific Indexing Services I SCIPIOI JIFACTOR

[23] Lei Zh., Shouju R., Zuzho L., (2000), Self-organization based DSS framework, IEEE, 0-7803-6583-6/00, 609-614.

[24] Herghiligiu I.V., Lupu M.L., Paius C.M, Robledo C., Kobi A., (2013), Organizational employee seen as environmental knowledge fractal agents as a consequence of the certification with ISO 14001, 10th International Conference on Intellectual Capital, Knowledge Management \& Organisational Learning ICICKM 2013", 24-25 October, Washington, DC, USA, 524-532.

[25] Herghiligiu I.V., Lupu M.L., Robledo C., Kobi A., (2013), A new conceptual framework for environmental decision at the organizational level based on fractal philosophy, Environmental Engineering and Management Journal, 12 (5), pp. 1095-1102, ISSN: 1843-3707.

[26] Herghiligiu I.V., Lupu M.L., Robledo C., (2012), Necessity of change environmental management system architecture - introduction, 2nd International Conference on Quality and Innovation in Engineering and Management, Cluj-Napoca, Romania, 175-178.

[27] Bin H., Gangyan L., (2009), Configuration unit for product self-organizing configuration design and its application, Proceedings of Fifth International Conference on Natural Computing, IEEE, 468-472.

[28] Danli D., Leng J., Hongyan Zh., (2011), A ship manufacturing model for fractal-based green supply chain, Proceedings of MSIE 2011, IEEE, 22-25.

[29] Ryu K., Jung M., (2003a), Fractal approach to managing intelligent enterprises: Creating Knowledge Based Organizations, in Gupta, J.N.D., Sharma, S.K. (editor), Editura Idea Group, 312-348.

[30] Ryu K., Jung M., (2003b), Agent-based fractal architecture and modeling for developing distributed manufacturing systems, International Journal of Production Research, 41 (17), 4233-4255.

[31] Ryu K., Son Y., Jung M., (2003c) Modeling and specifications of dynamic agents in fractal manufacturing systems, Computers in Industry, 52 (2), 161-182.

[32] Ryu K., Jung M., (2004), Goal-orientation mechanism in the fractal manufacturing system, International Journal of Production Research, 42 (11), 2207-2225.

[33] Shin M., Jung M., (2004), MANPro: mobile agent-based negotiation process for distributed intelligent manufacturing, International Journal of Production Research, 42 (2), 303-320.

[34] Ryu K., Son Y., Jung M., (2003d), Framework for fractal-based supply chain management of e-Biz companies, Production Planning and Control, 14 (8), 720-733.

[35] Peters E., (1996), Chaos and Order in the Capital Markets, New York: John Wiley \& Sons.

[36] Standards Association of Romania - ASRO, (2005a), Sisteme de management de mediu. Cerinţe cu ghid de utilizare, SR EN ISO 14001: 2005.

[37] Standards Association of Romania - ASRO, (2005b), Sisteme de management de mediu. Linii directoare referitoare la principii, sisteme şi tehnici de aplicare, SR EN ISO 14004: 2005.

[38] Lozano M., Valles J., (2007), An analysis of the implementation of an environmental management system in a local public administration, Journal of Environmental Management, 82, 495-511.

[39] Hayes R., Dassen R., Schilder A., Wallage P., (2005), Principles of auditing. An Introduction to International Standards on Auditing, Second Edition, Prentice Hall, UK. 